\title{
Nitrogen management and biological nitrogen fixation in sorghum/pigeonpea intercropping on Alfisols of the semi-arid tropics
}

\author{
Joseph J. Adu-Gyamfi ${ }^{1}$, O. Ito ${ }^{2}$, T. Yoneyama ${ }^{3}$ and K. Katayama ${ }^{3}$ \\ ${ }^{1}$ ICRISAT Asia Center, Patancheru, Andhra Pradesh, 502 324, India \\ ${ }^{2}$ IRRI, P O Box 933, 1099 Manila, Philippines \\ ${ }^{3}$ National Agriculture Research Center, 3-1-1, Kannondai, Tsukuba, Ibaraki 305, Japan
}

Key words: biological nitrogen fixation, fertilizer $\mathrm{N}$ recovery, intercropping, pigeonpea, sorghum

\begin{abstract}
Pigeonpea (Cajanus cajan L. Millsp) and sorghum (Sorghum bicolor L. Moench), are grown as intercrops on soils typified by low nitrogen $(\mathrm{N})$, particularly Alfisols and Vertisols of the semi-arid tropical areas of India and East Africa. Proper management of fertilizer $\mathrm{N}$ in sorghum/pigeonpea intercropping systems is essential to enhancing biological nitrogen fixing ability of pigeonpea, and to increasing grain yields of sorghum.

In a 3-year study, we examined the effect of time and rates of fertilizer $\mathrm{N}$ application on biological $\mathrm{N}$ fixation (BNF) and fertilizer $\mathrm{N}$ recovery by pigeonpea and sorghum grown as a sole crop, and as an intercrop on an Alfisol in India. In 1993, N (50 kg N ha-1) was all applied at planting (basal) or at 40 days after sowing (delayed). During 1994-1995, four $\mathrm{N}$ rates $0,25,50$, and $100 \mathrm{~kg} \mathrm{ha}^{-1}$ were applied (i) $100 \%$ at planting (basal) or (ii) $67 \%$ at 40 days, and $33 \%$ at 60 days after sowing (delayed).

Delaying $\mathrm{N}$ fertilization until 40 days after sowing (DAS), rather than applying at sowing significantly increased $(p<0.001)$ total dry matter, grain yield (GY) and total N content (TNC) of the sorghum, but not of pigeonpea. Highest GY and TNC was recorded at an N rate of $50 \mathrm{~kg} \mathrm{ha}^{-1}$ with sole crop sorghum, and at $25 \mathrm{~kg}$ $\mathrm{ha}^{-1}$ for intercrop sorghum. Delaying $\mathrm{N}$ fertilization to sorghum significantly $(p<0.001)$ increased ${ }^{15} \mathrm{~N}$ recovery in the shoot from 15 to $32 \%$ in sole crop, and 10 to $32 \%$ in intercrop. Similarly, there was a significant ( $p<$ 0.001 ) increase in $\mathrm{N}$ recovery (calculated without ${ }^{15} \mathrm{~N}$, but by the difference between the nonfertilized $\mathrm{N}$ and fertilized plots) from $43-59 \%$ in sole crop and from $28-71 \%$ in intercrop sorghum. Pigeonpea fixed between $120-$ $170 \mathrm{~kg} \mathrm{ha}^{-1}$ of atmospheric $\mathrm{N}$ throughout the cropping season. Nitrogen application to the sorghum row, but not to the pigeonpea, enhanced BNF by pigeonpea and maximized fertilizer recovery by sorghum in a sorghum/pigeonpea intercropping.
\end{abstract}

\section{Introduction}

Pigeonpea and sorghum are important food grain crops in the semi-arid tropical areas in India, and Eastern Africa. Both crops are usually grown as intercrops on soils of low $\mathrm{N}$ content, and in dry environments where it is difficult to grow other food grains. Pigeonpea is able to meet a proportion of its own $\mathrm{N}$ requirement through biological $\mathrm{N}$ fixation (Kumar Rao et al., 1987). In addition, pigeonpea can increase the available phosphorus pool of cropping systems in which it is grown by accessing ironbound $\mathrm{P}$ to a greater extent than other crop species in Alfisols (Ae et al., 1990). Thus, the inclusion of pigeonpea in intercropping systems helps to minimize competition for $\mathrm{N}$ and $\mathrm{P}$ with the cereal component.

Nitrogen management in cereal/legume intercropping has received little attention in the semi-arid tropics (SAT) probably because farmers rarely apply $\mathrm{N}$ in intercropping systems. Reasons for this include unpredictable rainfall leading to low $\mathrm{N}$ use efficiencies, and the detrimental effect of fertilizer $\mathrm{N}$ on BNF by the legume. Naraian et al. (1980) and Tobita et al. (1994) reported that a moderate dose of $25-50 \mathrm{~kg} \mathrm{~N} \mathrm{ha}^{-1}$ was optimum for a sorghum/pigeonpea on an Alfisol in the SAT in India.

During a 3-year study, we investigated the rate and time of $\mathrm{N}$ fertilization on BNF by pigeonpea, and grain yield and fertilizer recovery by sorghum in sorghum/pigeonpea intercropping. The study also aimed to understand the extent to which pigeonpea grown in association with sorghum, instead of in pure stands, can help reduce the fertilizer $\mathrm{N}$ needs of sorghum on Alfisol typified by low $\mathrm{N}$ content.

\section{Materials and methods}

Two field experiments were carried out on a

This paper was originally published in T. Ando et al. (Eds.), Plant nutrition for sustainable food production and environment, 1997, Kluwer Academic Publishers, Dordrecht. 
medium-deep Alfisol (Ferric Luvisols; Udic Rhodustalf) at ICRISAT Asia Center, Patancheru (17 $\left.38^{\prime} \mathrm{N}, 78^{\circ} 21^{\prime} \mathrm{E}\right)$ India, during the 1993-1995 rainy seasons.

\section{Experiment 1 \\ Crop cultivation and management}

The soil had an average available moisture storage capacity of about $100 \mathrm{~mm}, \mathrm{pH}\left(\mathrm{H}_{2} \mathrm{O}\right) 6.2$, mineral $\mathrm{N}$ concentration of $40 \mathrm{mg} \mathrm{kg}^{-1}$, and available $P$ concentration (Bray II) $10 \mathrm{mg} \mathrm{kg}^{-1}$. The experiment was a $4 \times 3$ factorial, set out in a split-plot design with three replicates. Main treatments were four cropping systems, namely (i) sole crop sorghum (ii) sole crop pigeonpea (iii) intercrop sorghum/pigeonpea and (iv) a bare fallow treatment (to serve as a control plot for monitoring $\mathrm{N}$ dynamics in the soil). The sub-plot treatments were (i) no $\mathrm{N}$ fertilizer applied (NO), (ii) a rate of $50 \mathrm{~kg} \mathrm{~N} \mathrm{ha}^{-1}$ all applied at planting (basal) and (iii) $50 \mathrm{~kg} \mathrm{~N} \mathrm{ha}^{-1}$ applied at 40 days after sowing (delayed). All of the $\mathrm{N}$ fertilizer was applied by opening the furrows and banding at $5-8 \mathrm{~cm}$ depth. The $\mathrm{N}$ source was urea. In the intercropping treatment, $\mathrm{N}$ was applied only to sorghum rows. Phosphorus was basally broadcast on all the experimental plots at the rate of $20 \mathrm{~kg} \mathrm{ha}^{-1}$ as single superphosphate, and mixed in the surface 5 $\mathrm{cm}$ of soil.

Medium-duration pigeonpea [Cajanus cajan (L) Moench] cultivar ICP 1-6, and grain sorghum [Sorghum bicolor (L) Moench] hydrid CSH 5, were sown either as a sole crop or as intercrop. The spacings were $60 \times 30 \mathrm{~cm}$ for sole-cropped pigeonpea, $60 \times 15 \mathrm{~cm}$ was sole-cropped sorghum, and $60 \times 10 \mathrm{~cm}$ for both crops in the intercropping, which had a 2:1 (sorghum:pigeonpea) row proportion. This arrangement gave an identical number of plants on an area basis for each component in the sole and intercropping systems. Microplots measuring $90 \times 90 \mathrm{~cm}$ for sole-cropped pigeonpea, $45 \times 90 \mathrm{~cm}$ for sole-cropped sorghum, 50 $\times 90 \mathrm{~cm}$ for intercrop, and $45 \times 60 \mathrm{~cm}$ for the bare fallow plots, were demarcated at the center of each plot with iron pegs. The ${ }^{15} \mathrm{~N}-$ labelled urea (30 atom\% excess, Shoko Co. Ltd., Japan) was applied by banding to crop rows in all microplots, at the same time and rate as for the surrounding non-labelled urea.

\section{Crop harvest}

Shoot samples were taken from a $0.8 \mathrm{~m}^{2}$ area from each plot at 28, 40, and 78 days after sowing (DAS). At maturity (110 days for sorghum and 210 days for pigeonpea), an area of 4 rows by $4 \mathrm{~m}\left(9.6 \mathrm{~m}^{2}\right)$ was harvested to estimate total dry weight and grain yields. Plant samples were separated into leaves, stems and reproductive organs depending on the growth stage, dried at $70^{\circ} \mathrm{C}$ for $48 \mathrm{hr}$ and weighed.

Chemical analysis

Oven-dried shoot samples were ground to pass a 0.4mm screen for chemical analysis. Nitrogen in plant parts was estimated by the indophenol color formation method (Chaykin, 1969) after microKjeldhal digestion.

${ }^{15} \mathrm{~N}$ analysis and ${ }^{15} \mathrm{~N}$ recovery by crops

Four plants of each species were sampled at final harvest from the ${ }^{15} \mathrm{~N}$-treated microplots for the ${ }^{15} \mathrm{~N}$ enrichment analysis. Another set of 4 plants were sampled outside the microplot for ${ }^{15} \mathrm{~N}$ natural abundance $\left(\delta^{15} \mathrm{~N}\right)$ analysis. The natural ${ }^{15} \mathrm{~N}$ abundance in grains of pigeonpea and sorghum was estimated with a mass spectrometer (Finnigan Mat 251). The ${ }^{15} \mathrm{~N}$ enrichment was estimated with an ${ }^{15} \mathrm{~N}$ emission spectrometer (Jasco N-150).

The fractional contribution of $\mathrm{N}$ derived from fertilizer ( $\% \mathrm{~N}_{\text {dff }}$ ) and the ${ }^{15} \mathrm{~N}$ recovery by crops were calculated as:

$\% \mathrm{~N}_{\text {dff }}=\left(1-\right.$ atom $\%{ }^{15} \mathrm{~N}$ excess in pigeonpea or sorghum/atom $\%{ }^{15} \mathrm{~N}$ excess in fertilizer) $\times 100$

The fertilizer $\mathrm{N}$ recovery (FRN) was estimated as:

$\mathrm{FRN}=\mathrm{N}_{\mathrm{dff}} / \mathrm{N}$ applied $\times 100$,

where the amount of $\mathrm{N}$ derived from fertilizer $(\mathrm{Ndff})$ was calculated as the $\mathrm{N}$ total $\left(\mathrm{kg} \mathrm{ha}^{-1}\right) \times \% \mathrm{~N}_{\text {dff. }}$. Estimation of nitrogen fixation by pigeonpea The fractional contribution of fixed $\mathrm{N}$ derived from air $\left(\% \mathrm{Ndfa}_{\mathrm{da}}\right)$ by pigeonpea in this study, was estimated using a delta ${ }^{15} \mathrm{Na}$ value of $-2.1 \%$ for a mediumduration pigeonpea (ICP 1-6) grown solely on atmospheric $\mathrm{N}_{2}$ (Tobita et al.,1994). The amount of $\mathrm{N}$ fixed by pigeonpea was calculated as:

$\mathrm{N}_{\text {dfa }}=\mathrm{N}_{\text {total }} \times \% \mathrm{~N}_{\text {dfa }}$

where $\mathrm{N}_{\text {total }}$ is the total $\mathrm{N}$ accumulated by pigeonpea $\left(\mathrm{kg} \mathrm{ha}^{-1}\right)$.

\section{Experiment 2}

The experimental site was $20 \mathrm{~m}$ from Experiment 1. The physical and chemical characteristics of this soils were similar except that $\mathrm{N}$ content of the soil was lower at this site. The sorghum and pigeonpea cultivars used were the same as in Experiment 1.

The experiment was a $4 \times 4 \times 2$ factorial, set out in a split-split plot design with three replicates. Main treatments were four cropping systems as described in Experiment 1. The sub-treatments consisted of four $\mathrm{N}$ rates, $0,25,50$, and $100 \mathrm{~kg} \mathrm{ha}{ }^{-1}$, applied (i) $100 \%$ at planting (basal) or (ii) $67 \%$ at 40 days (25 in 1995), and $33 \%$ at 60 days (50 in 1995) after 
planting (delayed). The application method and source of $\mathrm{N}$ fertilizer, shoot sampling and estimation of total dry weight was done as described in Experiment 1.

\section{Estimation of Biological nitrogen fixation}

Xylem exudates were collected with a Pasteur syringe at 25,37 and 65 DAS after cutting plants at the base and placing sleeves of black silicon rubber tubing over the exposed root stumps. The proportion of $\mathrm{N}$ derived from air ( $\% \mathrm{Ndfa}$ ) by pigeonpea was estimated by the relative ureide abundance method (Peoples et al., 1989). The ureides (allantoin and allantoic acid) were measured together as phenyhydrazone derivative of glyxolate (Young and Conway, 1942). Nitrate was measured by the salicylic acid technique (Cataldo et al., 1975). The $\alpha$ amino- $\mathrm{N}$ contents of exudates were determined colorimetrically with ninhydrin (Yemm and Cocking, 1955).

\section{Data analysis}

All data were analysed using GENSTAT 5 Release 3.2 (Copyright 1995, Lawes Agricultural Trust Rothamsted Experimental Station), following standard analysis of variance procedures (Gomez and Gomez, 1984) .

\section{Results}

\section{Experiment 1}

Fertilizer nitrogen recovery ( $F N R$ )

By including a nonfertilized control, we could compare the conventional difference method of determining fertilizer $\mathrm{N}$ uptake, and the direct labelling $\left({ }^{15} \mathrm{~N}\right)$ method (Fig. 1). The $\mathrm{N}$ recovery by the conventional difference method was higher than by the labelling method. Delaying $\mathrm{N}$ fertilization to sorghum for 40 days significantly $(p<0.001)$ increased ${ }^{15} \mathrm{~N}$ recovery in shoot from 15 to $32 \%$ in sole crop, and 10 to $32 \%$ in intercrop. Similarly,

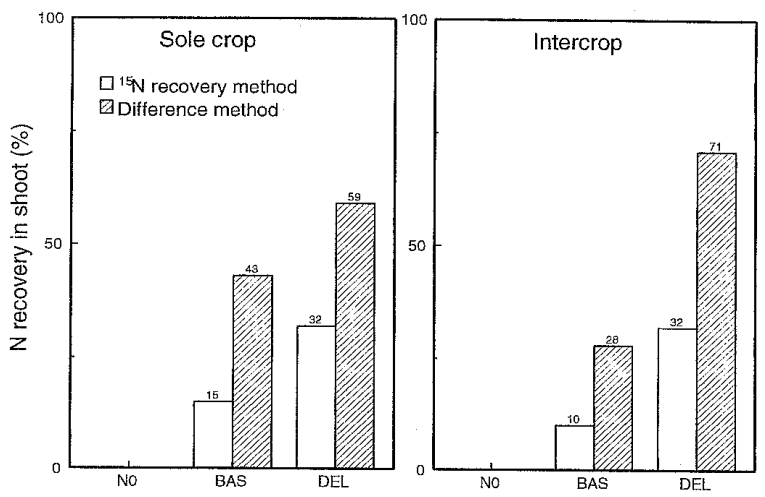

Fig. 1. Fertilizer $\mathrm{N}$ recovery in shoot of sorghum grown as a sole crop and as an intercrop with pigeonpea (Experiment 1). there was a significant $(p<0.001)$ increase in $\mathrm{N}$ recovery (by the difference method) from 43 to $59 \%$ in sole crop and from 28 to $71 \%$ in intercrop sorghum.

Nitrogen derived from fertilizer ( $N d f f)$, soil (Ndfs) and air (Ndfa)

Delaying $\mathrm{N}$ fertilization to sorghum by 40 days resulted in a two-fold increase of \%Ndff (Table 1). Soil $\mathrm{N}$ accounted for $84-100 \%$ of the total $\mathrm{N}$ in sorghum, and $26-44 \%$ in pigeonpea. Contrary to the $\%$ Ndff data, the \%Ndfs in sorghum was significantly higher when $\mathrm{N}$ fertilizer was applied at planting than at $40 \mathrm{DAS}$.

Biological $\mathrm{N}_{2}$ fixation by pigeonpea was estimated using the sorghum plants as a reference (Tobita et al., 1994). The proportion and amount of Ndfa by pigeonpea, calculated from $\delta^{15} \mathrm{~N}$ values in grain of sorghum ranged from +2.3 to $+4.1 \%$, and -0.5 to $1.6 \%$ in pigeonpea. The $\% \mathrm{Ndfa}$ values ranged from $57-74 \%$, but were not affected by timing of $\mathrm{N}$ fertilization (Table 1). Pigeonpea fixed 120-170 kg $\mathrm{N}$ ha ${ }^{-1}$ of atmospheric $\mathrm{N}$ throughout the cropping season. The amount was slightly higher when pigeonpea was grown in association with sorghum than when grown as a sole crop.

\section{Experiment 2}

Total Dry Matter Yield (TDMY) and $N$ accumulation A $25 \mathrm{~kg} \mathrm{~N} \mathrm{ha}^{-1} \mathrm{ha}^{-1}$ applied as "delayed N" gave the highest grain yield of intercropped sorghum compared to $50-100 \mathrm{~kg} \mathrm{~N} \mathrm{ha}^{-1}$ for sole-cropped sorghum (Fig. 2). Nitrogen accumulation by sorghum (sole and intercropped) was higher in the delayed than in the basal treatments.

Estimation of nitrogen derived from atmosphere (Ndfa)

In pigeonpea, fixed $\mathrm{N}$ is mainly translocated as ureide- $\mathrm{N}$, hence the proportion of ureide- $\mathrm{N}$ to the other nitrogenous solutes (nitrate and $\alpha$-amino acids) in xylem exudates is a good indicator of \% $\mathrm{Ndfa}$. The \%Ndfa by sole and intercropped pigeonpea before the first dose of delayed fertilization (25 DAS), second dose application (37 days) and 65 days were estimated.

There was a marked decrease in \%Ndfa in the sole crop but not in intercropped pigeonpea as fertilizer rates increased (Fig. 3). Intercropped pigeonpea derived about $80 \%$ of the $\mathrm{N}$ in plant from air compared to $60 \%$ by sole crop at 65 DAS.

\section{Discussion}

The 3 year study clearly demonstrates that there is a high potential for increasing grain yield of sorghum 
Table 1. Fractional contribution of plant $\mathrm{N}$ derived from fertilizer (\%Ndff), from soil (\%Ndfs), and from atmosphere (\%Ndfa) of sorghum and pigeonpea in sole crop and intercropping systems at harvest

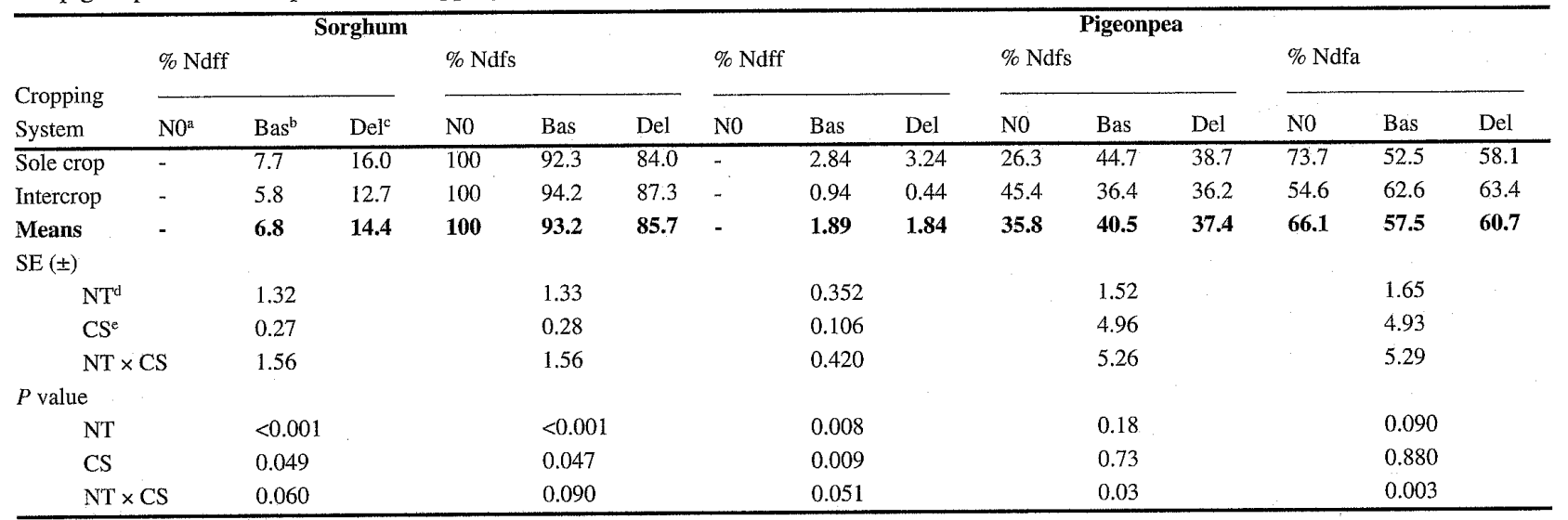

aNO : No N fertilizer.

${ }^{b}$ Bas : $\mathrm{N}$ application of $50 \mathrm{~kg} \mathrm{~N} \mathrm{ha}^{-1}$ at planting (basal).

Del : $\mathrm{N}$ application of $50 \mathrm{~kg} \mathrm{~N} \mathrm{ha}^{-1}$ at 40 days after sowing (delayed).

${ }^{\mathrm{d}} \mathrm{NT}$ : Timing of $\mathrm{N}$ application.

${ }^{\text {e }} \mathrm{CS}$ : Cropping system.

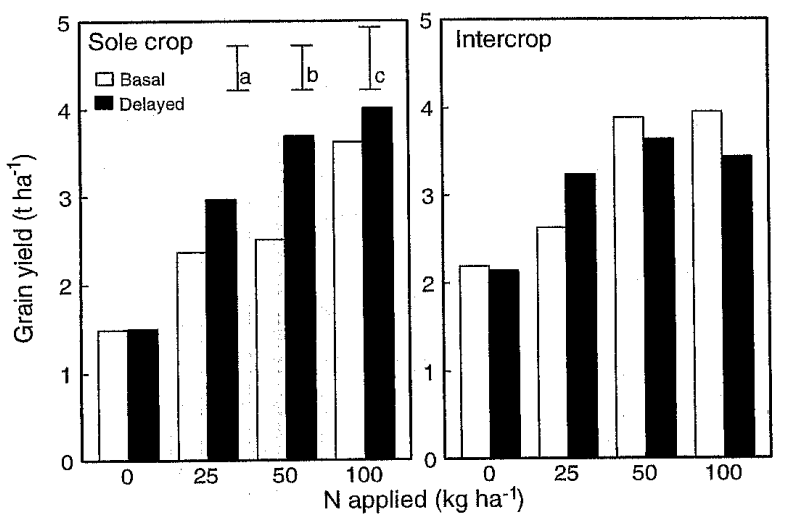

Fig. 2. Mean grain yields of sole crop and intercrop sorghum in response to timing and rates of $\mathrm{N}$ application during a 2-year period. Bars indicate LSD $(p<0.05)$ values when comparing (a) cropping systems $\times$ time $(\mathbf{b})$ cropping systems $\times$ fertilizer, and (c) cropping systems $\times$ time $\times$ fertilizer.

and enhancing BNF by pigeonpea through intercropping without necessarily increasing the quantity of fertilizer $\mathrm{N}$ use. In sorghum/pigeonpea intercropping, $\mathrm{N}$ application to the sorghum, but not to pigeonpea was effective in enhancing BNF by pigeonpea and maximizing fertilizer recovery by sorghum. Delaying fertilizer $\mathrm{N}$ application for 25 DAS resulted in a higher grain yield and total $\mathrm{N}$ amount than basal application. When sorghum is intercropped with pigeonpea, moderate $\mathrm{N}$ fertilization of $25 \mathrm{~kg} \mathrm{ha}^{-1}$ was optimum for grain yield and total $\mathrm{N}$ accumulation, compared to $50 \mathrm{~kg} \mathrm{~N}$ ha $^{-1}$ when grown as a sole crop (Fig. 2). Similar results were reported by Naraian et al. (1980), and Tobita et al. (1994) who recommended a moderate dose of $25-30 \mathrm{~kg} \mathrm{ha}^{-1}$ for sorghum/pigeonpea

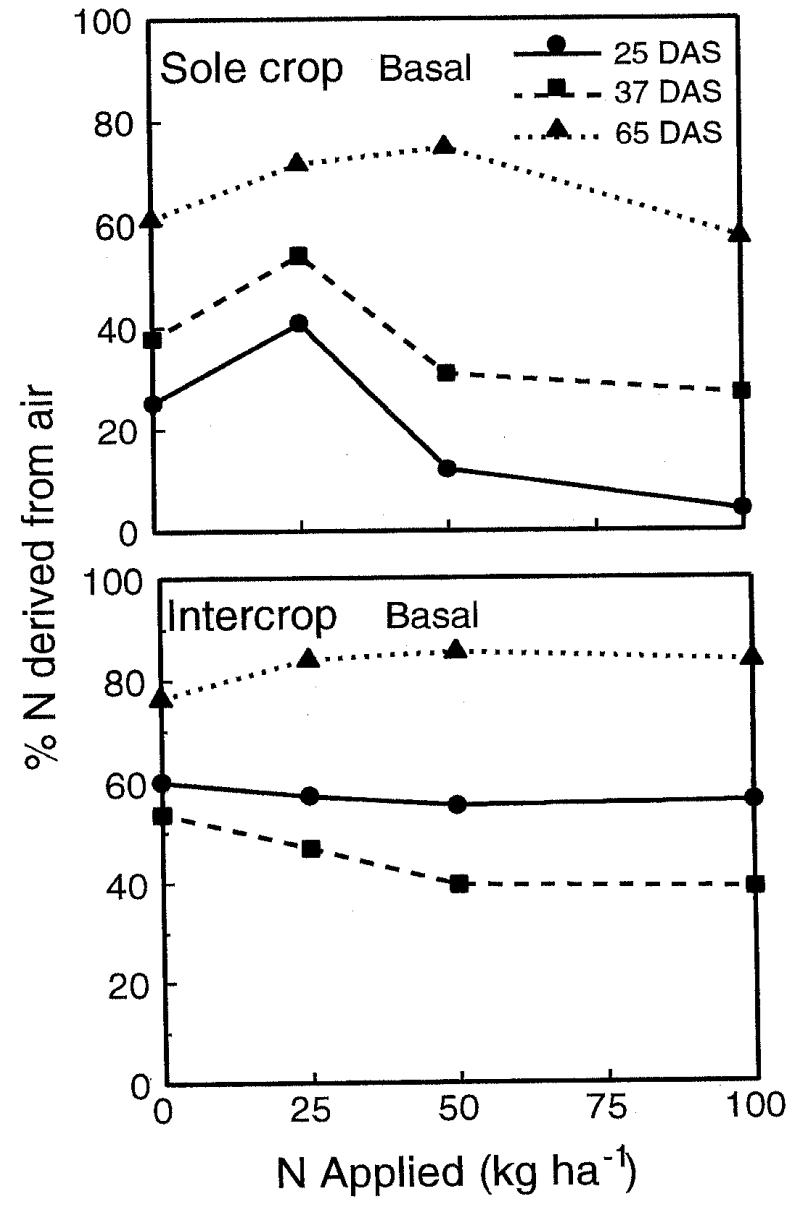

Fig. 3. Proportion of $\mathrm{N}$ derived from air (\%Ndfa) by pigeonpea estimated by the relative ureide abundance method.

intercrops on an Alfisol in the SAT in India. The results indicate that pigeonpea grown in association with sorghum, instead of pure stands, can help 
reduce the fertilizer $\mathrm{N}$ needs of sorghum in soils typified by low $\mathrm{N}$.

In the SAT where intercropping is commonly practised, "basal N" is preferred to "delayed N" application by farmers because it is considered that the crops require $\mathrm{N}$ for their early growth. As reported by Adu-Gyamfi et al. (1996), however, the mineral $\mathrm{N}$ content in soil due to the long dry fallow period, in most cases, is adequate for early establishment of the component sorghum because of less competition for soil $\mathrm{N}$ by the associated pigeonpea.

\section{Fertilizer nitrogen recovery in plant}

Fertilizer $\mathrm{N}$ recovery (FNR) was calculated for crop uptake with or without the use of labelled ${ }^{15} \mathrm{~N}$ has been extensively reviewed (Jansson and Persson 1982; Jenkinson et al. 1985; Strong, 1995). Where the two FNR methods have been compared, recovery is usually higher for the difference method than for the ${ }^{15} \mathrm{~N}$ direct method. This is due to the "added $\mathrm{N}$ interaction" described by Jenkinson et al. (1985), which is also commented on in detail by Jansson and Persson (1982). However, few studies have compared the FNR of sorghum and pigeonpea in intercropping syștems.

Using the difference method, FNR in the shoot by sole crop sorghum was higher for the delayed (59\%) than for the basal treatment (43\%). When sorghum was grown in association with pigeonpea, $71 \%$ of fertilizer $\mathrm{N}$ was recovered when fertilization was delayed compared to $28 \%$ for basal (Experiment 1). The plant ${ }^{15} \mathrm{~N}$ recovery method showed a similar trend to the difference method, although the values were lower (Fig. 1). Similar results were reported on an Alfisol by Adu-Gyamfi et al. (1996), Moraghan et al. (1984), and Tobita et al. (1994). Thus, FNR by sorghum was enhanced when (i) intercropped with pigeonpea compared to when grown as a sole crop and (ii) $\mathrm{N}$ application was split-delayed compared to $100 \%$ application at planting.

\section{Biological nitrogen fixation}

The amount of $\mathrm{N}$ fixed by pigeonpea estimated by the ${ }^{15} \mathrm{~N}$ natural abundance method, during the entire growth period of 210 days, was $120 \sim 170 \mathrm{~kg} \mathrm{~N} \mathrm{ha}{ }^{-1}$. The amount was higher by intercropped than by sole-cropped pigeonpea (Katayama et al., 1995; Tobita et al., 1994).

The ${ }^{15} \mathrm{~N}$ natural abundance and the ${ }^{15} \mathrm{~N}$ enrichment methods for estimating BNF by legumes are costly because they involve the use of mass and emission spectrophotometers, usually not available in laboratories of developing countries. The relative abundance of ureides (the proportion of ureides, $\alpha$ amino acids and $\mathrm{NO}_{3}-\mathrm{N}$ concentration in xylem sap) has been used to estimate \%Ndfa by soybean and other ureide producing leguminous crops. Field application of this method to estimate $\% \mathrm{Ndfa}$ by intercropped-pigeonpea does not exist in literature, although Peoples et al. (1989) estimated \% Ndfa of pot-cultured young pigeonpea plants.

The $\%$ Ndfa estimated by the relative ureide abundance method supported the findings that BNF was enhanced by intercropping. The only drawback of using this method is that the amount of $\mathrm{N}$ derived from air at final sampling could not be estimated because xylem exudates could not be extracted from pigeonpea after flowering. The woody nature of stem of pigeonpea makes it difficult to extract xylem exudates irrespective of the soil moisture. Thus, the estimation of Ndfa by the natural abundance method is more desirable to quantify the total contribution of BNF by pigeonpea during the entire cropping period. Nevertheless, values of the \%Ndfa by sole crop and intercrop pigeonpea at flowering compare favourably with reported values for sole-cropped and intercropped pigeonpea (Adu-Gyamfi et al., 1996; Katayama et al., 1995; Tobita et al., 1994).

\section{Conclusions}

The 3 year study clearly demonstrated that there is a high potential for increasing grain yield of sorghum and enhancing BNF by pigeonpea through intercropping and proper timing of $\mathrm{N}$ without necessarily increasing the quantity of fertilizer $\mathrm{N}$ use. In sorghum/pigeonpea intercropping, $\mathrm{N}$ application to the sorghum, but not to the pigeonpea, enhanced BNF by pigeonpea and maximum fertilizer recovery by sorghum. In semi-arid regions, heavy rains that occur at the onset of the rainy season may lead to a substantial leaching of accumulated soil mineral $\mathrm{N}$ during the long dry fallow period. Since the crop need for $\mathrm{N}$, and the capacity for $\mathrm{N}$ uptake are small, delaying fertilizer application for 4-5 weeks can result in increased sorghum grain and dry matter yields, and enhanced BNF by pigeonpea.

\section{References}

Adu-Gyamfi J J, Katayama K, Gayatri Devi, Rao T P and Ito O 1996 Improvement of soil and fertilizer nitrogen use efficiency in intercropping. In Dynamics of root and nitrogen in cropping systems of the semi-arid tropics Eds. O Ito, C Johansen, J J Adu-Gyamfi, K Katayama J V D K Kumar Rao and T J Rego. pp 493-506. Japan International Research Center for Agricultural Sciences (JIRCAS), JIRCAS International Agriculture series No. 3 Tsukuba, Japan. Cultio Corporation, Tsukuba. 
Ae N, Arihara J, Okada K, Yoshihara T and Johansen C 1990 Phosphorus uptake by pigeonpea and its role in cropping systems of the Indian subcontinent. Science 284, 477-480.

Cataldo D A, Haroon M, Schrader L E and Youngs V L 1975 Rapid colorimetric determination of nitrate in plant tissue by nitration of salicylic acid. Comm. Soil Sci. Plant Anal. 6, 7180.

Chaykin S 1969 Assay of nicotinamide deaminase. Determination of ammonium by the indophenol reaction. Anal. Biochem. 32, 375-382.

Gomez K A and Gomez A A 1984 Statistical procedures for agricultural research. 2nd ed. John Willey and Sons, New York.

Jansson S L and Persson J 1982 Mineralization and immobilization of soil nitrogen. In Nitrogen in Agricultural soils. Ed. J Stevension. pp 229-252. Agronomy series NO. 22, ASA, CSSA, SSSA. Madison, WI.

Jenkinson D S, Fox R H and Rayner J H 1985 Interactions between fertilizer nitrogen and soil nitrogen — the so-called 'priming' effect. J. Soil Sci. 36, 425-444.

Katayama K, Ito O, Matsunaga R, Adu-Gyamfi J J, Rao T P and Anders M M 1995 Nitrogen balance and root behavior in four pigeonpea-based intercropping systems. Fert. Res. 42, 315319.

Kumar Rao J V D K, Thompson J A, Sastry P V S S, Giller K E and Day J M 1987 Measurement of $\mathrm{N}_{2}$ fixation in field-grown pigeonpeas [Cajanus cajan (L) Millsp] using ${ }^{15} \mathrm{~N}$-labelled fertilizer. Plant and Soil 101, 107-113.

Moraghan J T, Rego T J and Buresh R J 1984 Labeled nitrogen fertilizer research with urea in the semi-arid tropics. III Field studies on Alfisols. Plant and Soil 80, 193-203.

Naraian P, Verma B, and Singhal A K, 1980 Nitrogen economics through intercropping of pigeonpea and rainfed sorghum. Ind. J. Agron. 25, 190-196.

Peoples M B, Hebb D M, Gibson A H and Herridge D F 1989. Development of the xylem ureide assay for the measurement of nitrogen fixation by pigeonpea (Cajanus cajan (L.) Millsp). J. Exp. Bot. 40, 535-542.

Strong W M 1995 Nitrogen fertilization of upland crops. In Nitrogen fertilization in the environment.Ed. P E Bacon. pp 129-169. Marcel Dekker, Inc., Hong Kong.

Tobita S, Ito O, Matsunaga R, Rao T P, Rego T J, Johansen C and Yoneyama T 1994. Field evaluation of nitrogen fixation and use of nitrogen fertilizer by sorghum/pigeonpea intercropping on an Alfisol in the Indian semi-arid tropics. Biol. Fertil. Soils $17,241-248$.

Yemm E W and Cocking E C 1955 The determination of amino acids with ninhydrin. The Analyst 80, 209-213.

Young G and Conway C F 1942 On the estimation of allantoin and allantoic acid by the Rimini-Schryver reaction. J. Biol. Chem. 142, 839-853. 